I N F ORM A I K A

Jurnal Informatika, Manajemen dan Komputer, Vol. 8 No. 2 , Desember 2016

eISSN : 2580-3042

pISSN : 1979-0694

\title{
SISTEM INFORMASI PENJUALAN GAME PC BERBASIS WEB PADA TOKO OE GAMES MENGGUNAKAN PHP
}

\author{
Juanda Sihombing ${ }^{1}$, Hayatullah Khumaini ${ }^{2}$ \\ ${ }^{1,2,3}$ Sekolah Tinggi Manajemen Informatika Dan Komputer ( STMIK ), Dumai, Riau \\ Jln. Utama Karya Bukit Batrem Dumai-Riau Kode Pos 28811 \\ E-mail: juandasihombing_1993@yahoo.co.id
}

\begin{abstract}
Game tidak hanya dimainkan oleh anak-anak dan remaja saja, bahkan orang dewasa pun juga memainkanya Game itu sendiri dibagi menjadi 2 golongan yaitu game online dan game offline. Telah dilakukan penelitian di Toko Oe Games dimana permasalahan yang dijadikan dasar yaitu untuk meningkatkan Penjualan, khususnya untuk menambah konsumen dari luar daerah kota Dumai. Sehingga hal ini dapat meningkatkan penjualan. Oleh karena itu, dirancang sebuah sistem informasi berbasis web sebagai solusi dari masalah yang dihadapi di toko Oe Games. Hasil analisis menunjukkan pengembangan sistem yang digunakan dari perancangan web ini adalah agar dapat mempermudah petugas Kasir pengolahan data Penjualan. Dengan adanya sistem informasi Berbasis WEB ini, maka hasil penjulan dan laporan yang dihasil kan akan lebih baik dan efektif.
\end{abstract}

Kata Kunci : Sistem Informasi, Game, PHP

\section{PENDAHULUAN}

Game mempunyai banyak manfaat yaitu dapat membantu manusia dalam menghilangkan kepenatan atau mengisi waktu luang. Selain itu sebagai sarana penghibur, hobi, ataupun menjadi ajang bisnis yang dapat menghasilkan sejumlah uang.

Game itu sendiri dibagi menjadi 2 golongan yaitu game online dan game offline. Disini penulis mendapatkan inspirasi untuk membuat sebuah aplikasi berbasis web, yang nantinya akan membantu user di toko Oe games dalam menjalankan usahanya yaitu menggunakan web. Adapun kendala yang dialami pemilik toko dalam menjual game dan produk di toko adalah kurangnya media untuk mempromosikan game dan produk - produk yang ada di toko. Selama ini para konsumen hanya dari masyarakat dumai saja karena tidak diketahui keberadaan toko tersebut oleh pecinta game yang ada diluar Dumai, padahal ini adalah jamannya dimana orang-orang bisa membeli suatu barang yang ada di daerah lain tanpa harus datang ke daerah tersebut.

Aplikasi web tersebut mempunyai fungsi yaitu sebagai sarana dan prasarana mediator bagi toko Oe games dalam menjual atau mempromosikan penjualan game dan produkproduk yang ada di toko keseluruh masyarakat melalui web yang akan dibuat. dengan adanya sistem ini, nantinya para penggemar game baik dari luar Dumai akan dapat melihat game atau produk-produk toko melalui web tersebut. Di dalam web tersebut para calon pembeli akan dapat melihat dan memesan game atau produk yang diinginkan. Dengan demikian hal ini dapat menunjang penjualan pada toko Oe games yang pada sebelumya hanya memiliki konsumen di daerah Dumai saja.

\section{a. Pengertian Informasi}

Informasi adalah data yang telah diolah menjadi sebuah bentuk yang berarti bagi penerimanya dan bermanfaat dalam pengambilan keputusaan saat ini atau mendatang (Jogiyanto, 2009: h.8).

\section{b. Pengertian Data}

Data adalah suatu istilah majemuk yang berarti fakta atau bagian dari fakta yang mengandung arti yang dihubungkan dengan kenyataan, simbol-simbol, gambar-gambar, angkaangka, huruf-huruf, atau simbol yang menunjukkan suatu ide, objek, kondisi, atau situasu dan lain-lain (Tata sutabri, 2012:h.2).

\section{Metodologi Penelitian}

Kerangka penelitian yang di gunakan dalam penelitian ini adalah sebagai berikut : 
I N F ORM T I K A

Jurnal Informatika, Manajemen dan Komputer, Vol. 8 No. 2 , Desember 2016

eISSN : 2580-3042

pISSN : 1979-0694

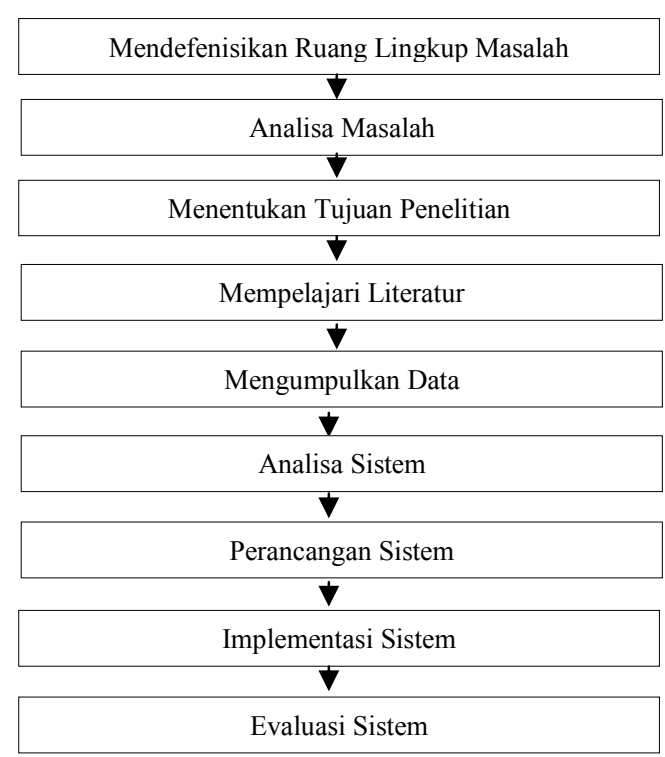

Gambar 1. Kerangaka Penelitian

\section{HASIL DAN PEMBAHASAN}

a. ASI yang sedang Berjalan

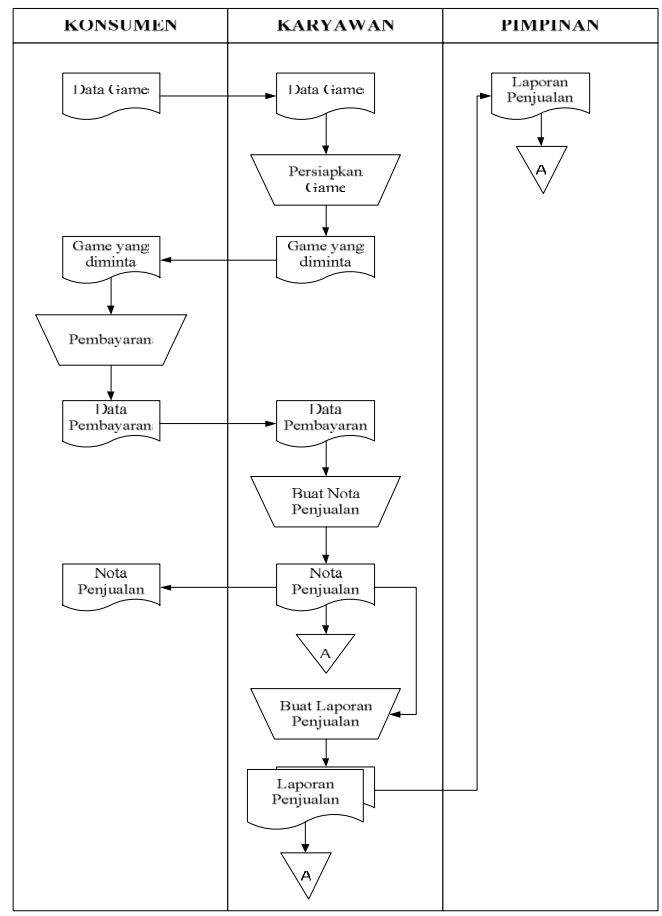

Gambar 2. Asi Berjalan

Keterangan :

1. Member menjelaskan game yang ingin dibeli kepada karyawan.

2. Karyawan menyediakan game yang diminta.

3. Member melakukan pembayaran.

4. Karyawan membuatkan nota penjualan

5. Nota penjualan diberikan kepada member.

6. Karyawan membuat laporan penjualan berdasarkan transaksi penjualan yang ada.
7. Laporan penjualan diberikan kepada pimpinan.

b. Aliran Sistem Baru (ASI)

Adapun aliran sistem baru dapat dilihat pada tabel 8 sebagi berikut :

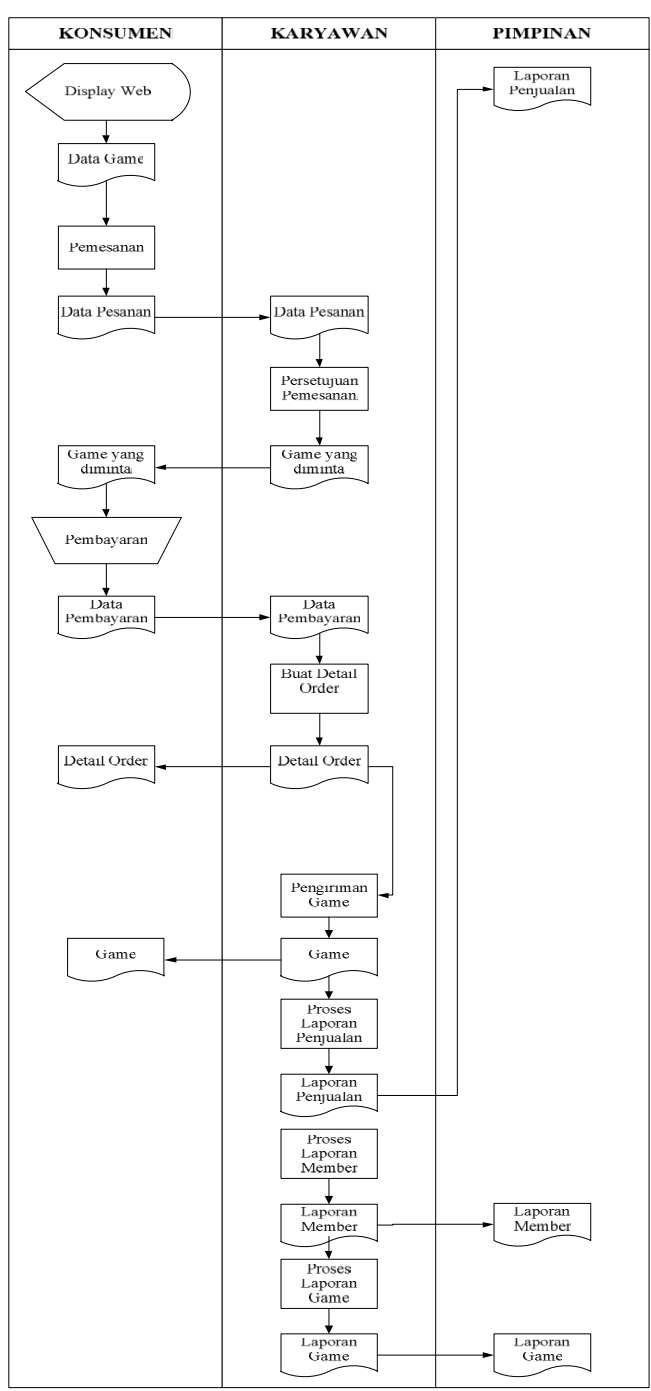

Gambar 3. Aliran Sistem Baru (ASI)

\section{Keterangan :}

1. Member mengakses game yang ada.

2. Member melakukan pemesanan game

3. Karyawan memeriksa pemesanan dan melakukan persetujuan.

4. Setelah pemesanan disetujui, member melakukan pembayaran.

5. Karyawan yang telah menerima pembayaran membuat detail order.

6. Detail order diberikan kepada member.

7. Karyawan melakukan pengiriman game.

8. Pimpinan mengakses laporan penjualan, laporan member dan laporan game. 
I N F O R M A I I A

Jurnal Informatika, Manajemen dan Komputer, Vol. 8 No. 2 , Desember 2016

eISSN : 2580-3042

pISSN : 1979-0694

\section{c. Context Diagram}

Adapun context diagram dapat digambarkan seperti pada gambar 3 dibawah ini :

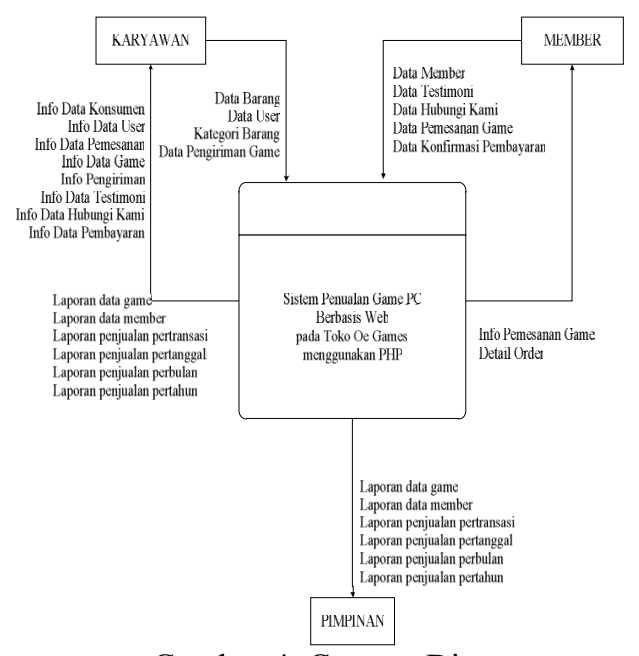

Gambar 4. Context Diagram

d. Data Flow Diagram

Adapun data flow diagram dapat digambarkan seperti pada gambar 4 dibawah ini :

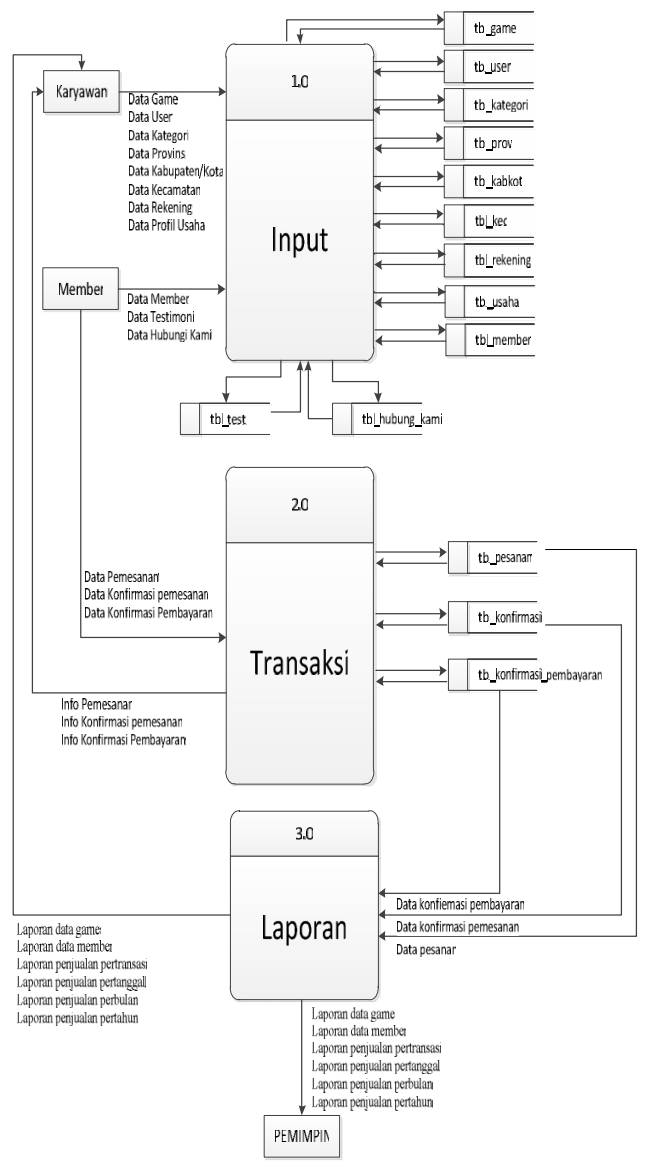

Gambar 5. Data Flow Diagram level 1

\section{Implementeasi Sistem}

Adapun langkah-langkah penggunaan program adalah sebagai berikut:

1. Buka browser seperti modzila, google chrome, dan sebagainya.

Lalu ketik www.oegames.net pada address bar browser anda.

2. Maka akan muncul tampilan website oegames.net.

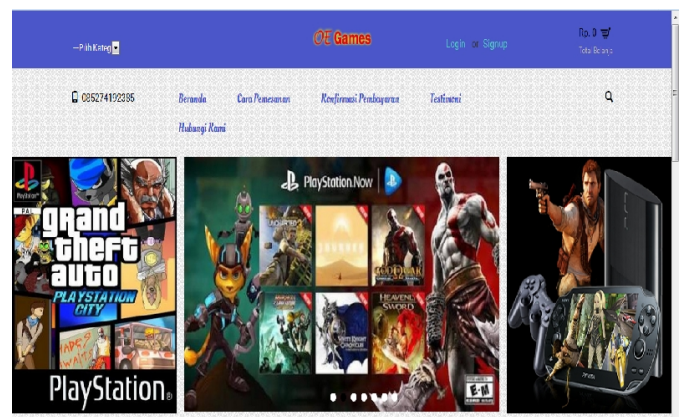

Gambar 6. Gambar tampilan website oegames

3. Ditampilan tersebut ada beberapa pilihan yaitu beranda, cara pemesanan, konfirmasi pembayaran, testimony, dan hubungi kami.

4. Apabila ingin memesan, klik slide pada gambar tampilan dibawah ini.

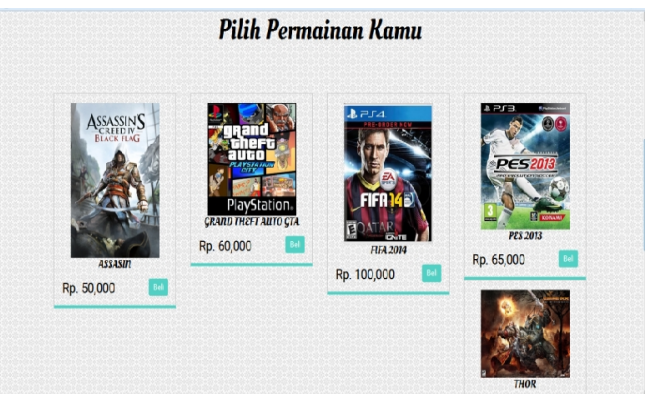

Gambar 7. Pilihan game

5. Pilih game sesuai selera dengan mengklik tombol beli pada game yang dipilih.

6. Setelah itu pesanan akan tersimpan secara otomatis pada keranjang belanja seperti gambar dibawah ini

\section{Keranjang Anda}

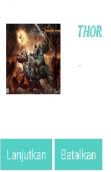

Gambar 8. Tampilan keranjang belanja 
I N F ORM I T I A

Jurnal Informatika, Manajemen dan Komputer, Vol. 8 No. 2 , Desember 2016

eISSN : 2580-3042

pISSN : 1979-0694

7. Lalu klik tombol lanjutkan pada tampilan keranjang belanja anda tersebut.

8. Setelah itu akan muncul tampilan seperti dibawah ini

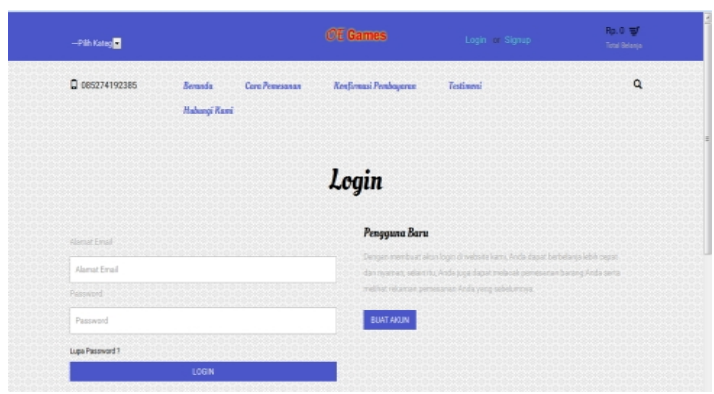

Gambar 9. Tampilan login

9. Masukkan id anda, apabila belum memiliki akun, silahkan mendaftar dengan mengklik tombol buat akun pada tampilan gambar diatas.

10. Setelah itu akan muncul tampilan konfirmasi pembayaran, lalu klik tombol kirim.

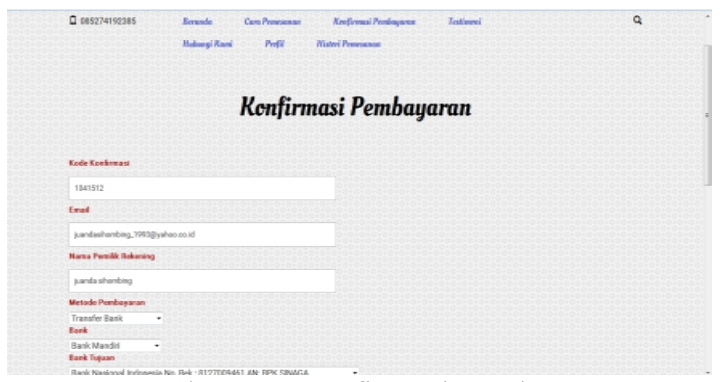

Gambar 10. Konfirmasi pembayaran

11. Lalu akan muncul tampilan konfimasi pembayaran yang berarti bahwasanya anda sudah mentransfer biaya untuk pembelian barang tersebut.

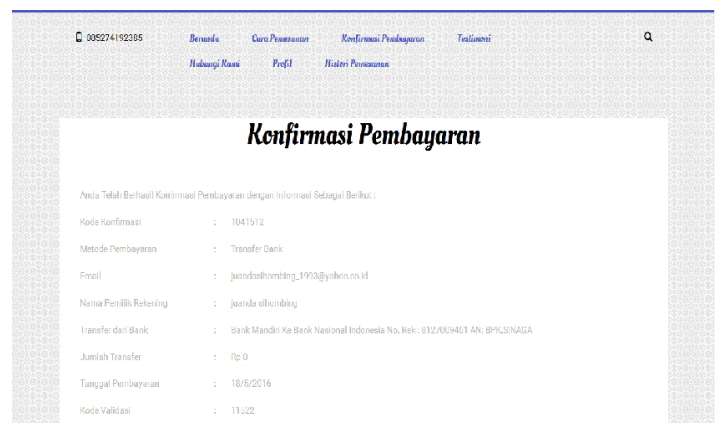

Gambar 11. Tampilan konfirmasi pembayaran

Langkah langkah penggunaan program untuk admin yaitu:

1. Ketik localhost admin oegames pada address bar browsing anda, lalu login terlebih dahulu.

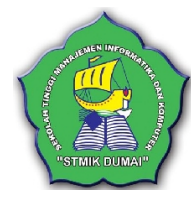

2. Setelah login, akan muncul tampilan dibawah ini yang terdiri dari halaman utama, data master, pemesanan, persetujuan \& pengiriman, laporan, pengaturan, dan keluar.

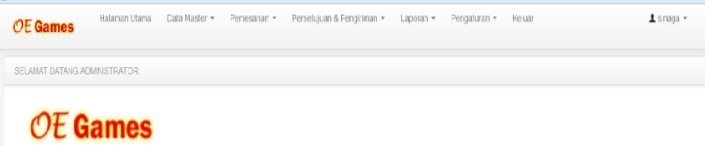

Gambar12. Tampilan halaman utama admin

3. Untuk meninjau pemesanan, klik persetujuan dan pengiriman pada tampilan lalu pilih persetujuan terlebih dahulu, dan akan muncul tampilan seperti dibawah ini lalu berikan tanda ceklis pada kolom approval.

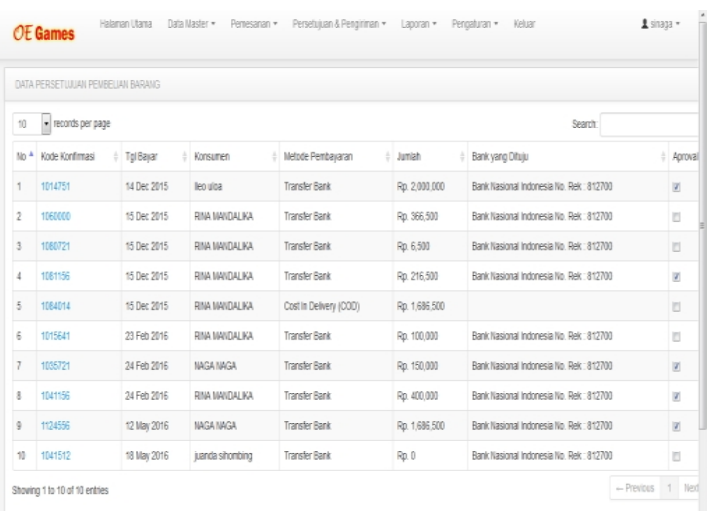

Gambar 13. Tampilan persetujuan

4. Setelah itu klik kembali tampilan persetujuan dan pengiriman lalu pilih pengiriman, akan muncul gambar dibawah ini

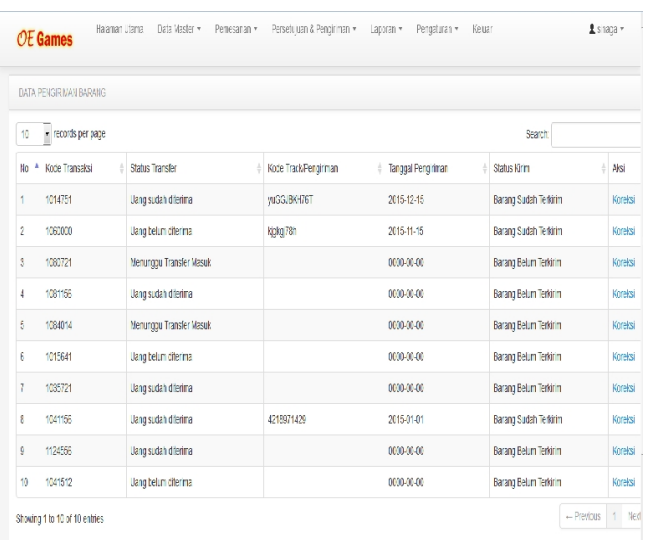

Gambar 14. Tampilan pengiriman 
I N F O RM A T I K A

Jurnal Informatika, Manajemen dan Komputer, Vol. 8 No. 2 , Desember 2016

eISSN : 2580-3042

pISSN : 1979-0694

5. Klik tombol koreksi dan akan muncul tampilan dibawah ini lalu isi data detail pengiriman, lalu klik tombol kirim.
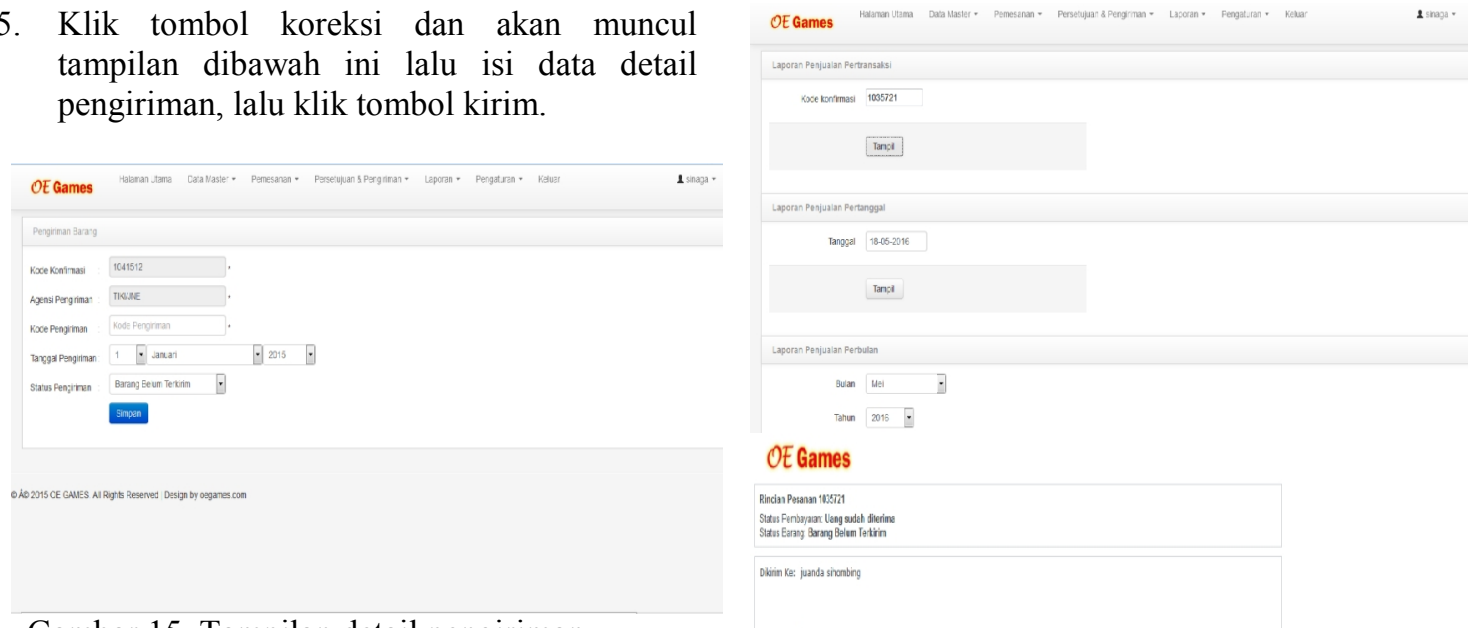

Gambar 15. Tampilan detail pengiriman

6. Lalu klik laporan setelah mengklik tombol kirim diatas.

7. Adapun pada laporan ini, tampilannya sebagai berikut apabila memilih laporan stock barang.
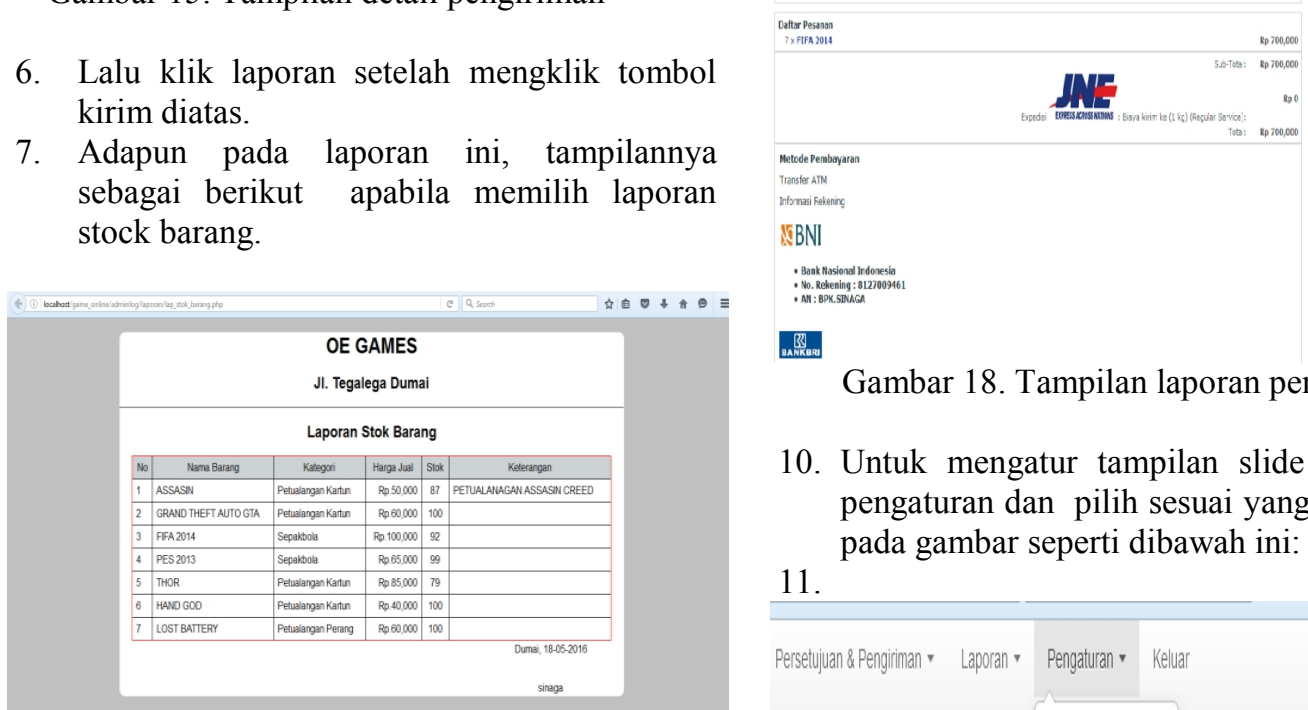

Gambar16. Tampilan laporan stock barang

8. Akan tampil gambar dibawah ini apabila memilih laporan data member

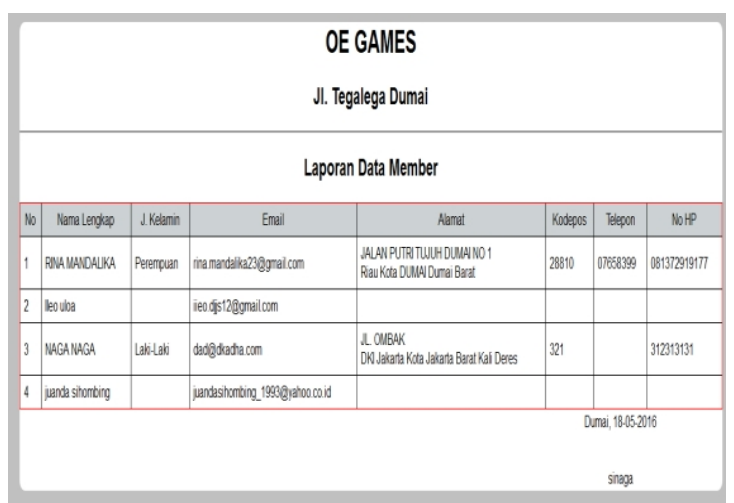

Gambar17. Tampilan laporan data member

9. Akan tampil gambar dibawah ini apabila memilih laporan penjualan

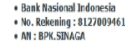

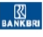

Gambar 18. Tampilan laporan penjualan

10. Untuk mengatur tampilan slide show, klik pengaturan dan pilih sesuai yang di inginkan pada gambar seperti dibawah ini:

11.

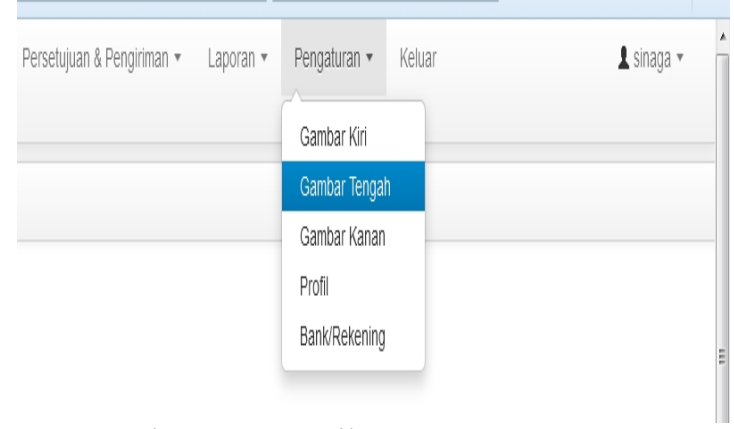

Gambar 19. Tampilan pengaturan slide show

\section{KESIMPULAN}

Ada beberapa kesimpulan yang diperoleh dari penelitian ini adalah sebagai berikut :

1. Website pengunjung dan website halaman admin dapat di akses melalui internet.

2. Sistem dapat diakses dengan beberapa gadget yang berbeda.

3. Untuk mendapat tampilan yang bagus , sistem harus diakses menggunakan PC, netbook maupun laptop. 
4. Sistem informasi penjualan game pc pada toko Oegames Dumai bisa dipesan secara online.

5. Pengunjung ataupun costumer dapat mengetahui informasi dari website toko Oegames Dumai.

6. Pada laporan di halaman administrator, ada beberapa laporan yang terdiri dari laporan data game, laporan data member, laporan data penjualan pertransaksi, laporan penjualan pertanggal, laporan penjualan perbulan, laporan penjualan pertahun

7. Untuk masuk ke dalam halaman administrator, pengguna harus memiliki data login berupa kode user, jabatan dan password.

\section{REFERENSI}

Alan Nur Aditya. (2011). Jago PHP dan MySQL. Dunia Komputer. Bekasi.

Agus Saputra. (2012). Membangun Aplikasi Toko Online dengan PHP dan

SQL Server. PT Elex Media Komputindo. Jakarta.

Fatansyah. (2012). Basis Data. Informatika. Bandung.

Hanif Al Fatta. (2007). Analisis dan Perancangan Sistem Informasi. Andi. Yogyakarta.

Indrajani. (2011). Perancangan Basis Data Dalam All In1. Gramedia. Jakarta.

Jogiyanto. (2009) .Sistem Teknologi Informasi. Andi. Yogyakarta.

Kusrini. (2007). Strategi Perancangan dan Pengelolaan Basis Data. Andi. Yogyakarta.

Lukmanul Hakim. (2014). Rahasia Inti Master PHP dan MySQL(improved). CV. Lokomedia. Yogyakarta.

M. Rudyanto Arief. (2011). Pemorograman Web Dinamis Menggunakan PHP dan MySQL. Andi. Yogyakarta.

Sutarman. (2009). Pengantar Teknologi Informasi. PT Bumi Aksara. Jakarta.

Wahana Komputer. (2012). Mudah Membuat Portal Berita Online Dengan PHP dan mySQL. Andi. Yogyakarta. 